\title{
Degradation of Elevated Concentrations of Phenol Using Two-Stage Immobilized Cell Reactor with Bacillus subtilis and Acinetobacter lwoffii
}

\section{Bahobail AS}

Department of Biology, Faculty of Science, Taif University, Kingdom of Saudi Arabia

\begin{abstract}
Two vertical rotating immobilized cell reactors (VRICRs), one with the Bacillus subtilis, BDCC-TUSA-3 for bisurfactant (surfactin) production and the other with Acinetobacter Iwoffii, accession number KM985371 for phenol biodegradation were constructed, with polyurethane foams as the attachment support. They were separately optimized for surfactin production and degradation of phenol respectively. Then, the two reactors were combined to form a two-stage VRICR where an appropriate fraction of Bacillus sp. reactor effluent,

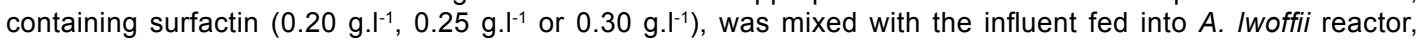
containing various concentrations of phenol (1500 mg.l-1, $1870 \mathrm{mg.l}^{-1}$ and $2250 \mathrm{mg}^{-1} \mathrm{I}^{-1}$. The VRICR was operated continuously over more than two weeks. Cell growth, cell viability, degradation efficiency of phenol and specific degradation rate (SDR) were followed over periods of operation. The best results were obtained when a steady state was reached with $45.6 \mathrm{~g} . \mathrm{l}^{-1}, 98 \%, 100 \%$ and $810 \mathrm{mg}$ phenol. $\mathrm{g}$ immobilized cells ${ }^{-1} \cdot \mathrm{h}^{-1}$ for cell growth, cell viability, degradation efficiency and SDR respectively. Additionally, surfactin was produced from reactor 1 at

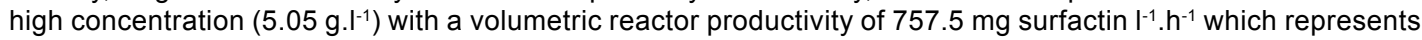
an extra added-value product that could markedly decrease operating costs. The efficient process for phenol degradation, with no secondary by-products, coupled with potential applicability of simultaneously produced surfactin that could be utilized in many industrial applications, makes the two-stage VRICR a potential candidate for a clean, cost-effective and environmentally sustainable process.
\end{abstract}

Keywords: Phenol; Biodegradation; A. lwoffii; B. subtilis; Surfactin; Immobilized cells; Two-stage bioreactor

\section{Introduction}

Phenol is toxic by ingestion, contact or inhalation and harmful to aquatic organisms [1] and has been included in the list of priority pollutants by the U.S. Environmental Protection Agency [2]. Phenol is used extensively in many industrial activities. This makes it a major environmental pollutant in many wastewater facilities, such as oil refineries, coking plants, pharmaceuticals, and plastic industries [3]. Therefore, these wastewater streams require proper treatment before being discharged. Compared to the currently used physio-chemical processes to remove phenol from wastewaters, the bioremediation using living microorganisms exhibits many advantages [4]. Bioremediation processes are simple, cost-effective, and environmentally friendly process with no hazardous intermediates being synthesized [5]. However, bioremediation processes have been limited by phenol inhibition to microbial cells. Many attempts have been used to overcome such limitations. These include the two-phase partitioning bioreactor (TPPB) [6], fluidized bed reactor (FBR) [7] and most importantly immobilized cell reactors (ICR) [5]. However, in all these studies, low phenol concentrations were tested with low biodegradation rates and productivities that do not satisfy industrial and environmental requirements. In previous investigation, a vertical rotating immobilized cell reactor (VRICR) was designed and built [8] and used for successful execution of a number of biotechnological processes with remarkably high reaction rates and volumetric productivities [9]. On the other hand, efficiency of phenol degradation could be further enhanced in presence of biosurfactants. Biosurfactants have excellent ability to emulsify hydrophobic compounds such as phenol [10] and work as mediators which increase their mass transfer rate into the aqueous phase and make them more bioavailable to microorganisms [11].

The objective of the present study was to investigate the capabilities of locally isolated A. lwoffii accession number KM985371 for phenol degradation using free-suspended cells. A two-stage VRICR was also built and tested to carryout continuous degradation of elevated concentrations of phenol in presence of the biosurfactant surfactin.

\section{Materials and Methods}

\section{Microorganisms}

The phenol-degrading A. lwoffii accession number KM985371 and the surfactin producing $B$. subtilis strain BDCC-TUSA-3 [12] were used.

\section{Chemicals and culture media}

All chemicals used were analytical reagents. The minimal salt media (MSM) was used in present study. It contained $\mathrm{KH}_{2} \mathrm{PO}_{4} 0.5 \mathrm{~g}$, $\mathrm{K}_{2} \mathrm{HPO}_{4} 0.5 \mathrm{~g}, \mathrm{CaCl}_{2} 0.1 \mathrm{~g}, \mathrm{NaCl} 0.2 \mathrm{~g}, \mathrm{MgSO}_{4} .7 \mathrm{H}_{2} \mathrm{O} 0.5 \mathrm{~g}, \mathrm{MnSO}_{4} 7 \mathrm{H}_{2} \mathrm{O}$ $0.01 \mathrm{~g}, \mathrm{FeSO}_{2} 7 \mathrm{H}_{2} \mathrm{O} 0.01 \mathrm{~g}, \mathrm{NH}_{4} \mathrm{NO}_{3} 1.0 \mathrm{~g}$ per liter. Deionized, distilled water was used for the experiments. The activated sludge samples were collected in a biological treatment system, Jeddah refinery, KSA.

\section{Bioreactor}

The VRICR comprises a double walled vessel, with a rotating shaft, driven by a motor extends into the vessel and is journalized in bearings fitted with suitable seals [8]. Two stacks of Immobilized Biomass Units

"Corresponding author: Bahobail AS, Department of Biology, Faculty of Science, Taif University, Kingdom of Saudi Arabia, Tel: +966 12-727-2020; Fax: +966 12-725-6300; E-mail: abahobail2016@yahoo.com

Received September 01, 2016; Accepted December 24, 2016; Published December 30, 2016

Citation: Bahobail AS (2016) Degradation of Elevated Concentrations of Phenol Using Two-Stage Immobilized Cell Reactor with Bacillus subtilis and Acinetobacter Iwoffii. J Pet Environ Biotechnol 7: 313. doi: 10.4172/2157-7463.1000313

Copyright: (c) 2016 Bahobail AS. This is an open-access article distributed under the terms of the Creative Commons Attribution License, which permits unrestricted use, distribution, and reproduction in any medium, provided the original author and source are credited. 


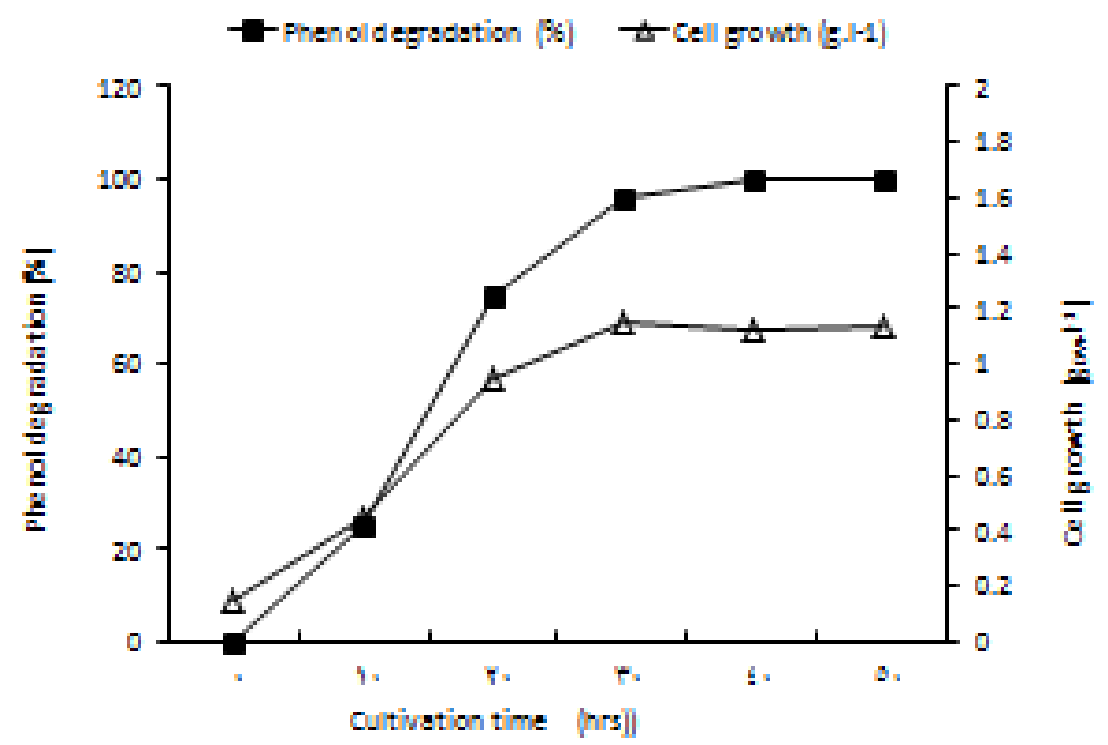

Figure 1: Pattern of cell growth and phenol degradation in batch culture using free-suspended cells of $A$. Iwoffii initial concentrations of $0.15 \mathrm{~g} . \mathrm{I}^{-2}$ and 1000 mg. $\mathrm{I}^{-2}$ were used for bacterial cells and phenol respectively.

\begin{tabular}{|c|c|c|c|c|c|}
\hline \multirow{2}{*}{ Surfactin $\left(g . .^{-1}\right)$} & \multicolumn{2}{|c|}{ Cell growth } & \multirow{2}{*}{ Phenol biodegradation (\%) } & \multirow{2}{*}{ Growth rate $\left(h^{-1)}\right.$} & \multirow{2}{*}{ SBR (mg phenol. g $^{-1}$ cell dry weight. $h^{-1}$ ) } \\
\hline & $\left(g . I^{-1}\right)$ & Viability (\%) & & & \\
\hline 0 & 1.05 & 92 & 74.6 & 0.19 & 64.5 \\
\hline 0.05 & 1.61 & 94 & 76 & 0.22 & 82.3 \\
\hline 0.1 & 1.96 & 94 & 93.1 & 0.26 & 90.1 \\
\hline 0.2 & 2.25 & 98 & 99.1 & 0.35 & 105.9 \\
\hline 0.4 & 1.27 & 90 & 91.8 & 0.29 & 68.65 \\
\hline 0.8 & 0.84 & 88 & 89 & 0.24 & 49.66 \\
\hline
\end{tabular}

Table 1: Effect of surfactin concentration on biodegradation of phenol in batch culture by free-suspended cells of $A$. Iwoffii.

(IBUs) are mounted on the shaft. Each IBU has a core of $97 \%$ porosity of polyurethane foam disc of 140 and $8 \mathrm{~mm}$ in diameter and thickness respectively, sandwiched between two perforated metal sheets except the top, the middle and bottom units in which polyurethane foam cores are mounted on only one perforated metal sheet to facilitate taking samples of the immobilized biomass entrapped into polyurethane foam discs. The IBU in each stack are spaced apart vertically and the respective stacks are also spaced apart vertically. Each IBU has a central hub fixed to the shaft by screws. Three blades extend substantially radially from the hub. These configurations provide a reasonable distribution of immobilized biomass within the bioreactor, facilitate smooth release of $\mathrm{CO}_{2}$ and allow simple and direct contact between fermentative substrate and immobilized biomass.

\section{Biomass (dry weight)}

Cell concentration in polyurethane foams (immobilized cells), or in bioreactor effluent (free cells) was determined by measuring absorbance at $600 \mathrm{~nm}$ using a spectrophotometer (UNICO, 2100, USA) which was subsequently correlated to standard curve. The growth rate $(\mu)$ was determined according to Pirt [13]. The following equation was used: $\mu=\left(\log \mathrm{X}_{2}-\log \mathrm{X}_{1}\right) / \operatorname{loge}$

Where, $\mathrm{X}_{1}$ and $\mathrm{X}_{2}$ are dry cell weight at beginning and end of period $(t)$ at mid-exponential phase respectively and loge is the natural logarithm.

\section{Analysis}

Phenol determination: Samples taken from culture broth were centrifuged in a micro centrifuge (HERMLE Z 233 M-2, Germany) at $10000 \mathrm{rpm}$ for $10 \mathrm{~min}$. Residual phenol was estimated in the supernatant by the method of Yang and Humphrey [14] based on rapid condensation with 4-amino-antipyrene followed by oxidation with alkaline potassium ferricsyanide giving a red color measured by UV spectrophotometery. The obtained OD values were then converted to phenol concentration using a phenol calibration curve. The oxygen transfer rate (OTR) was determined by direct measurement method described by Hirose [15]. The oxygen content in inlet and outlet gas streams was measured using oxygen analyzers. Then, the exact OTR was directly obtained by multiplying the difference in oxygen content by aeration rate, taking into consideration the gas low. Surfactin in reactor effluent after cell separation was estimated as described by Cooper [16].

\section{Results and Discussion}

\section{Phenol degradation by free cells of $A$. lwoffii in batch culture}

Growth pattern and phenol biodegradation by free cells of $A$. lwoffi: Figure 1 shows the growth pattern and phenol degradation by the A. lwoffii cells grown in batch culture. As evidenced, MSM with $1000 \mathrm{ppm}$ of phenol supported bacterial growth and multiplication with almost no lag phase. Maximum concentrations $1.15 \mathrm{~g} \mathrm{l}^{-1}$ was achieved for cell growth with almost complete phenol biodegradation. Moreover, both pattern of cell growth and phenol degradation confirmed a typical behavior for a growth-associated process. The specific growth rate of the bacterium was calculated based on the plot of log (cell DW at mid-exponential phase) versus time as described in the 'Materials and 


\begin{tabular}{|c|c|c|c|c|c|}
\hline \multirow{3}{*}{ Rotation speed (rpm) } & \multicolumn{5}{|c|}{ Steady state parameters } \\
\hline & \multicolumn{2}{|c|}{ Immobilized cells } & \multirow[t]{2}{*}{ viability } & \multirow[t]{2}{*}{ Free cells $\left(\right.$ g..$\left.^{-1}\right)$} & \multirow[t]{2}{*}{$M f / i^{*}(\%)$} \\
\hline & Glucose utilization (\%) & $\left(\right.$ g..$\left.^{-1}\right)$ & & & \\
\hline 0 & 89.2 & 68.1 & 70.6 & 0.45 & 0.66 \\
\hline 10 & 100 & 53.9 & 86.2 & 1.06 & 2 \\
\hline 15 & 100 & 42.5 & 96.4 & 1.75 & 4.1 \\
\hline 20 & 99.1 & 29.7 & 95.4 & 3.78 & 12.7 \\
\hline 25 & 86.3 & 16.8 & 96.1 & 5.23 & 31.1 \\
\hline
\end{tabular}

Table 2: Effect of rotation speed on cell growth and accumulation in polyurethane foam with the VRICR of the bacterium $A$. Iwoffii. MSM with $50 \mathrm{~g} . \mathrm{I}^{-1}$ of Maldex-15 was used.

methods' section [13]. The bacterium exhibited a specific growth rate of $0.31 \mathrm{~h}^{-1}$ which compared favorably with $0.29 \mathrm{~h}^{-1}$ obtained by Khaleifat [17]. Similarly, a growth associated processes were reported for phenol degradation by Erwengell americana [17] and by Ralstonia eutropha [18].

Effect of surfactin on cell growth and degradation rate of phenol by $A$. Iwoffii: Table 1 shows cell growth and phenol degradation by $A$. lwoffi $i$ in presence of various concentrations of surfactin. Generally, both cell growth and phenol degradation was greatly improved in presence of surfactin. The best performance was achieved with $0.20 \mathrm{~g} . \mathrm{l}^{-1}$ of surfactin with 2.25 g..$^{-1}$ and $98 \%$ for cell growth and cell viability, respectively. The highest degradation rate of $105.9 \mathrm{mg}$ phenol. $\mathrm{g}$ immobilized cells ${ }^{-1}$ . $\mathrm{h}^{-1}$ was also related to the highest growth rate of $0.35 \mathrm{~h}^{-1}$ at the same concentration of surfactin. Biosurfactants at proper concentration are known for their ability to enhance solubilization and emulcification of petroleum pollutants and subsequent increase in their bioavailability [19]. In view of the high water solubility of phenol, biosurfactants may enhance phenol degradation by other mechanisms. Biosurfactants could have stimulative effects on cell growth [20], reduction of phenol toxicity [21] and increased enzyme production by microorganisms through improvement of permeability of cell membrane and subsequent enzyme release and enhancement of enzyme stability [22,23].

Higher surfactin concentrations decreased markedly both cell growth and phenol degradation. Similar results were obtained by Whang et al. [24].

\section{Degradation of phenol by immobilized cell systems}

Immobilization of $A$. Iwoffii cells into polyurethane foams: In order to enhance attachment of $A$. lwoffii cells into polyurethane foams, the VRICR was constructed as described in the Materials and Methods section and inoculated with $A$. lwoffii. It was firstly fed with MSM containing 50 g. $1^{-1}$ of Maldex-15 as the carbon source at a high feed rate of $1800 \mathrm{mll}^{-1}$ to maximize cell growth into polyurethane foams and remove the non-attached cells as well. The bioreactor was rotated at 0,10 , 15,20 and $25 \mathrm{rpm}$. Aeration rate was manipulated to insure OTR of 90.0 $\mathrm{mM} \mathrm{O}_{2} \cdot \mathrm{l}^{-1} \cdot \mathrm{h}^{-1}[9]$. Samples were taken at regular intervals and analyzed for free and immobilized cells and residual carbon source. The results are shown in Table 2. It is clear that rotation speed had a pronounced effect on biomass concentration in polyurethane foams. Cultivation without rotation resulted in a steady increase in immobilized cells; 68.1 g. $l^{1-1}$ were found after 5 days. However, incomplete utilization of carbon source was observed, most probably due to cell over-growth into polyurethane foams and limitation in mass transfer for both oxygen and nutrients. The mass ratio of free to immobilized cells $\left(\mathrm{M}_{\mathrm{ff} / \mathrm{i}}\right)$ was only $0.66 \%$, which reflects an extremely slow growth rate of immobilized biomass similar to those obtained previously with the bacterium $B$. subtilis [9]. With the highest rotation speed (25 rpm), cell leakage from polyurethane foams into surrounding medium was probably higher than cell growth in polyurethane foams. The concentration of immobilized cells decreased dramatically after reaching a maximum value to attain only $16.8 \mathrm{~g} . \mathrm{l}^{-1}$ at the end of attachment period (Table 2). The highest $\mathrm{M}_{\mathrm{f} / \mathrm{I}}$ value of $31.1 \%$ was reached and a steady state was never reached. Glucose utilization was only $86.4 \%$.

Steady state with complete utilization of Maldex-15 was achieved only at rotation speed of $15 \mathrm{rpm}$. Immobilized cell concentration of 42.5 g. $l^{-1}$ was maintained. Under such conditions, growth of immobilized $A$. lwoffii cells was apparently balanced by cell leakage into surrounding medium with $\mathrm{M}_{\mathrm{f} / \mathrm{I}}$ of $4.10 \%$. In an earlier publication, a similar growth pattern was observed with the bacterium $B$. subtilis [9] but with much lower immobilized cell concentrations of 27.0 g.t ${ }^{-1}$. Thus, A. lwoffii appears to attach more successfully to polyurethane foams.

Adaptation of immobilized cells of $A$. lwoffii to phenol: The VRICR of $A$. lwoffii, described above, after reaching a steady state

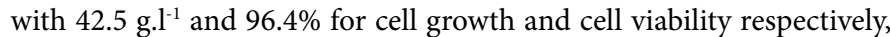
was fed with MSM supplemented with various concentrations of both Maldex-15 and phenol as carbon sources. This was performed by stepwise and simultaneous increases from to 0.00 to 1000 for phenol and decreases from 50.0 to 0.00 g. l $^{-1}$ for Maldex- 15 concentrations in reactor influent. Samples from reactor effluent were collected and analyzed for residual carbon sources and cell growth. Changes in carbon source concentrations were executed after reaching a steady state of the previous combination. Figure 2 shows the results. After 14 days (approximate 460 generations), VRICR was operating under steady state conditions with phenol concentration of $1000 \mathrm{mg}^{-1} \mathrm{l}^{-1}$, as the only carbon source in reactor influent with almost complete phenol degradation. During this period, immobilized cell concentration remained almost constant (44 g..$^{-1}$ ) with cell viability of more than $96 \%$. On the contrary, a gradual increase in SDR was noticed as concentration of phenol increased and reached its maximum value of $550 \mathrm{mg}$ phenol. g immobilized cells ${ }^{-1}$ . $\mathrm{h}^{-1}$ (Figure 2). This is in concordance with other researchers [25] who reported an enhancement in phenol degradation rate of Pseudomonas fluorescence KNU417 at higher concentrations. Elias et al., [26] further demonstrated that the preliminary acclimation of bacterial cells to the pollutant is a suitable strategy to shorten the start-up period of biofilters and ensure longer successful operation.

Continuous degradation of elevated concentrations of phenol by a two-stage VRICR of $A$. lwoffii and $B$. subtilis: Firstly, a VRICT of $B$. subtilis (bioreactor 1 ) was constructed and operated continuously over 10 days as described in an earlier publication [9] (Table 3). After reaching a steady state with immobilized cell concentration of 30.45 g. $\mathrm{l}^{-1}$ and surfactin content of $5.05 \mathrm{~g}^{-1} \mathrm{l}^{-1}$, it was connected to bioreactor 2 containing $43.6 \mathrm{~g}, \mathrm{l}^{-1}$ of phenol-adapted immobilized cells of $\boldsymbol{A}$. lwoffii, to form a two-stage VRICR. In order to supply bioreactor 2 with surfactin at the required concentration, an appropriate fraction from bioreactor 1 effluent containing surfactin was combined with MSM containing different concentrations of phenol before it was fed into bioreactor 2 at constant feed rate of $1800 \mathrm{ml}^{-\mathrm{h}^{-1}}$. Three feeding scenarios 


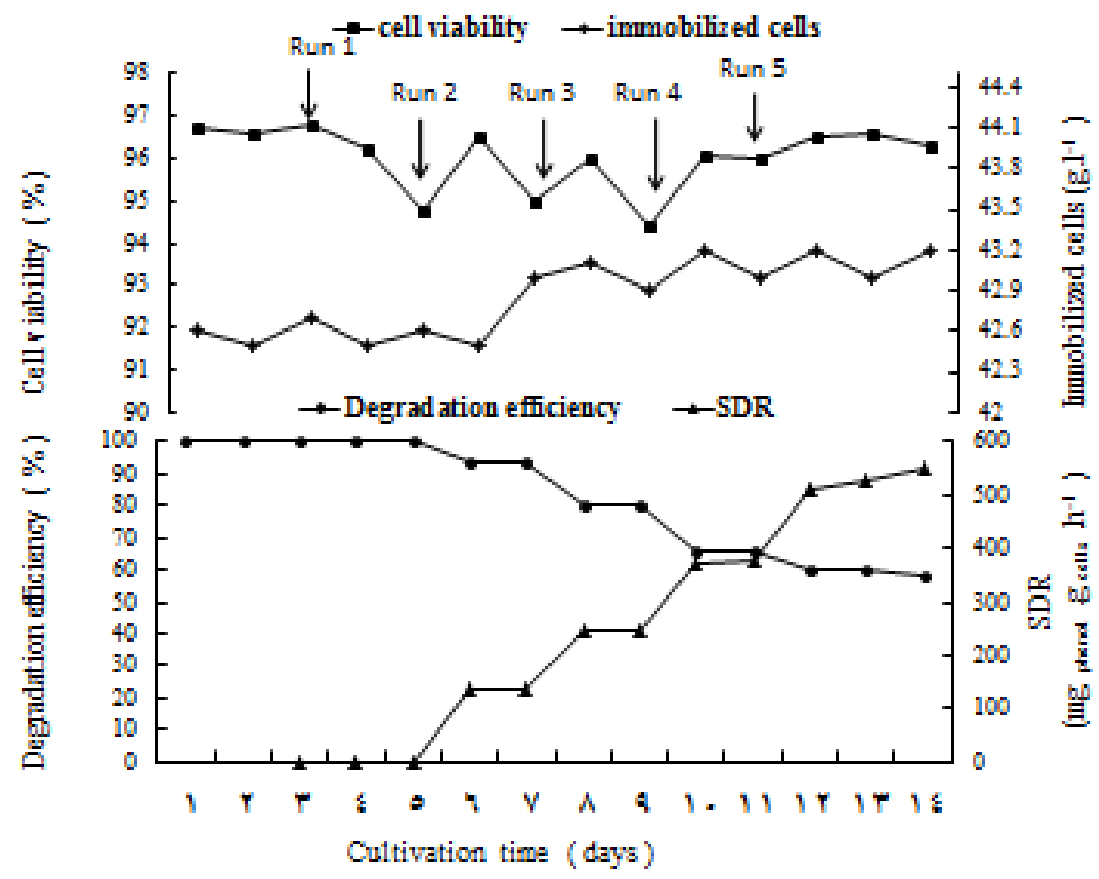

Figure 2: Performance of immobilized cell reactors of $A$. Iwoffii during adaptation on phenol days 1 to 3 : steady state reached at the end of cell attachment period. Runs 1 to 5: Feeding at $40 \mathrm{~g} \mathrm{l}^{-1}+100 \mathrm{mg} \mathrm{l}^{-1} ; 30 \mathrm{~g} \mathrm{l}^{-1}+200 \mathrm{mg} \mathrm{l}^{-1} ; 20 \mathrm{~g} \mathrm{l}^{-1} ; 400 \mathrm{mg} \mathrm{l}^{-1}+10 \mathrm{~g} \mathrm{l}^{-1}+800 \mathrm{mg} \mathrm{l}^{-1} ; 0.0 \mathrm{~g} \mathrm{l}^{-1}+1000 \mathrm{mg} \mathrm{l}^{-1}$ of maldex 15 and pheno; respectively.

\begin{tabular}{|c|c|}
\hline Parameters & Steady state \\
\hline Surfactin (g.l-1) & 5.05 \\
\hline Productivity $\left(\right.$ mg surfactin. I $\left.^{-1} . \mathrm{h}-1\right)$ & 757.5 \\
\hline Immobilized cells $\left(\mathrm{g} . \mathrm{I}^{-1}\right)$ & 30.45 \\
\hline Cell viability $(\%)$ & 90.5 \\
\hline Free Cells $\left(\mathrm{g} . \mathrm{I}^{-1}\right)$ & 6.76 \\
\hline Mf/l (\%) & 22.16 \\
\hline
\end{tabular}

${ }^{*}$ Continuous operation was conducted after the first week (period of cell attachment into polyurethane foams within the bioreactor). Complete rich medium

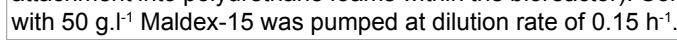

Table 3: Steady state optimum parameters for continuous surfactin production by immobilized cells of Bacillus subtilis.

to bioreactor 2 were tested. Firstly, and in order to supply bioreactor 2

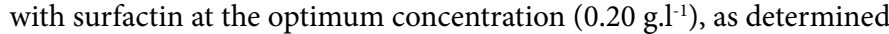
above, $71.29 \mathrm{ml}$ from bioreactor 1 effluent containing 0.36 g..$^{-1}$ surfactin was combined with $1728.71 \mathrm{ml}$ of MSM supplemented with phenol and pumped to bioreactor 2. Secondly, $89.11 \mathrm{ml}$ from bioreactor 1 effluent containing 0.45 g. ${ }^{1-1}$ surfactin was combined with 1710.89 $\mathrm{ml}$ of MSM supplemented with phenol and pumped to bioreactor 2 . Thirdly, $106.93 \mathrm{ml}$ from bioreactor 1 effluent containing $0.54 \mathrm{~g}^{-1} \mathrm{l}^{-1}$ surfactin was combined with $1693.07 \mathrm{ml}$ of MSM supplemented with phenol and pumped to bioreactor 2. Biodegradation of three different phenol concentrations; 1500,1870 and 2250 mg..$^{-1}$ were tested. Phenol concentration increased in feed line to bioreactor 2 when steady state, with complete degradation, was reached with the previous one. Performance of the two-stage bioreactor was monitored by checking bioreactor 2 effluent for SDR and degradation efficiency of phenol. Also, immobilized cell concentrations were followed. Figure 3 shows the results. The best results were obtained when MSM supplemented with $0.25 \mathrm{~g}^{-1} \mathrm{l}^{-1}$ surfactin and $2250 \mathrm{ppm}$ phenol was pumped into bioreactor 2. A steady state was reached with complete removal of phenol, and 45.6 g. $1^{-1}, 97.4 \%$ cell growth and cell viability respectively. The highest SDR of $960 \mathrm{mg}$ phenol.g immobilized cells ${ }^{-1} \cdot \mathrm{h}^{-1}$ was also achieved under such conditions. This most probably due to presence

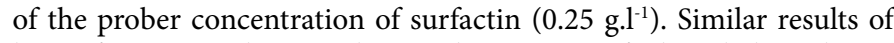
biosurfactant production during the process of phenol degradation have been reported to enhance efficiency of degradation by Candida tropicalis [27]. The obtained values for SDR are similar to those reported in literature [1]. However, the two-stage VRICR operating in presence of surfactin has longevity of operation and overall degradation rate of 9.0 and 1.8 times higher than those obtained for phenol degradation by pure culture of $A$. lwoffii in batch culture and those reported by selected microbial consortium in a two phase partitioning bioreactor (TPPB) [1] in continuous operation, respectively (Table 2). Certainly, this will be of great importance when such process is to be considered for industrial implementation.

With the highest surfactin concentration $\left(0.3\right.$ g.l $\left.{ }^{-1}\right)$, a steady state conditions was reached but with lower degradation efficiencies $(88.5 \%)$, lower cell concentration and cell viability of 39.8 g..$^{-1}$ and $93.2 \%$ respectively (Figure 3 ). Whang et al. [24] reported that application of biosurfactants at high concentrations inhibited microbial growth of Acinetobacter sp. strain PD12 and thus decrease the degradation efficiency of phenol by both free and immobilized cells. Since the concentration of immobilized cells and cell viability decrease a possible toxicity issues seemed more plausible.

\section{Conclusion}

The two stage VRICR constituted by A. lwoffii and B. subtilis operating in presence of various concentrations of biosurfactant, surfactin, was able to efficiently degrade elevated concentrations of phenol, as the only source of carbon and energy. As phenol concentration was increased in reactor influent, higher concentrations of surfactin had to be introduced in order to maintain complete phenol degradation. Surfactin concentration of $0.25 \mathrm{~g}^{-1} \mathrm{l}^{-1}$ of was found to be the most convenient for immobilized biomass to support complete phenol degradation. Up to 2250 g. $\mathrm{l}^{-1}$ of phenol in reactor influent were completely degraded with the highest SDR of $0.96 \mathrm{~g}$ phenol.g immobilized cells $\mathrm{h}^{-1}$ which is almost 15 fold increases compared to 
Citation: Bahobail AS (2016) Degradation of Elevated Concentrations of Phenol Using Two-Stage Immobilized Cell Reactor with Bacillus subtilis and Acinetobacter Iwoffii. J Pet Environ Biotechnol 7: 313. doi: 10.4172/2157-7463.1000313

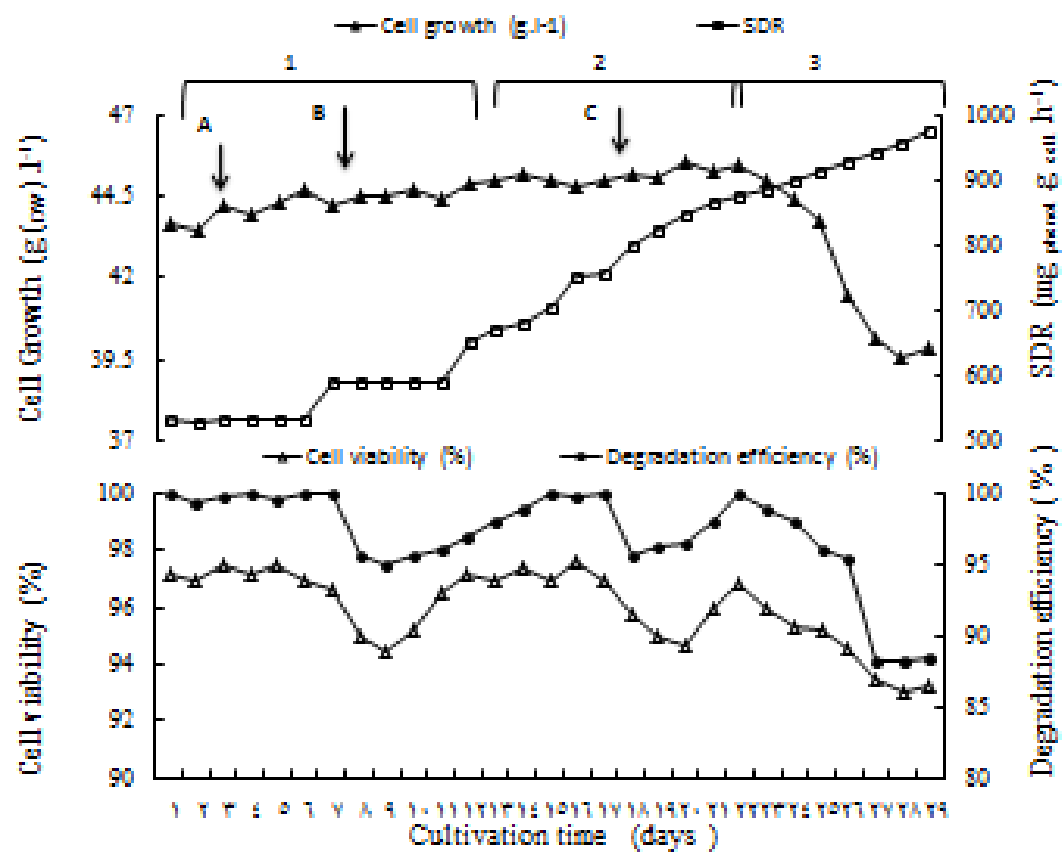

Figure 3: Continuous biodegradation of elevated concentration of phenol using immobilized cells of $A$. Iwoffii (Bioreactor 2) supplied with various concentration of surfactin from bioreactor 1 . Feed line contained $0.2 \mathrm{~g} . \mathrm{l}^{-1}(1), 0.25 \mathrm{~g} . \mathrm{l}^{-1}(2)$ and $0.3 \mathrm{~g} . \mathrm{l}^{-1}$ of surfactin (3); feed line contained $1500 \mathrm{mg} . \mathrm{l}^{-1}(\mathrm{~A}), 1870 \mathrm{mg} . \mathrm{l}^{-1}(\mathrm{~B})$ and $2250 \mathrm{mg} . \mathrm{l}^{-1}$ of Phenol (C).

batch culture using free-suspended cells of $A$. lwoffii. This indicates that phenol degradation must have benefited by both presence of surfactin and the increase in immobilized biomass. An extra bioreactor effluent stream with 5.05 g..$^{-1}$ of surfactin produced from Maldex-15, a cheap by-product from corn industry, represents additional benefits that could justify a cost-effect process for bioremediation of industrial wastewater with elevated phenol concentrations.

\section{Acknowledgement}

The authors are grateful to Department of Academic Affairs, Taif University, Kingdom of Saudi Arabia, for the financial support for this work.

\section{References}

1. Prpich GP, Daugulis AJ (2005) Enhanced biodegradation of phenol by a microbial consortium in a solid-liquid two phase partitioning bioreactor. Biodegradation 16: 329-339.

2. Environmental Protection Agency (EPA) (1977) Sampling and analysis procedure for screening of industrial effluents for priority pollutants; EPA: Cincinnati, $\mathrm{OH}, \mathrm{USA}$

3. Arutchelvan V, Kanakasabai V, Nagarajan S, Muralikrishnan V (2005) Isolation and identification of novel high strength phenol degrading bacterial strains from phenol-formaldehyde resin manufacturing industrial wastewater. J Hazard Mater 127: 238-243.

4. Jiang L, Ruan Q, Li R, Li T (2013) Biodegradation of phenol by using free and immobilized cells of Acinetobacter sp. BS8Y. J. Basic Microbiol. 53: 224-230.

5. Luckarift HR, Sizemore SR, Farrington KE, Fulmer PA, Biffinger JC, et al. (2011) Biodegradation of medium chain hydrocarbons by Acinetobacter venetianus $2 \mathrm{AW}$ immobilized to hair-based adsorbent mats. Biotechnol Progr 27: $1580-1587$.

6. Guieysse B, Cirne MD, Mattiasson B (2001) Microbial degradation of phenanthrene and pyrene in a two-liquid phase-partitioning bioreactor. Appl Microbiol Biotechnol 56: 796-802.

7. Carbajo J, Boltes K, Leton $P$ (2010) Treatment of phenol in an anaerobic fluidized bed reactor (AFBR): continuous and batch regime. Biodegradation 21: 603-613.
8. Amin GA, Doelle HW (1989) Vertical rotating immobilized cell reactor of the bacterium Z. mobilis for stable long-term continuous ethanol production. Biotech Techniques 3: 95-100.

9. Amin GA, Bazaid S, Abd-El-Halim M (2013) Two-stage immobilized cel bioreactor with Bacillus subtilis and Rhodococcus erythropolis for simultaneous production of biosurfactant and biodesulfurization of model oil. Petroleum Science and technology 31: 2250-2257.

10. Lai CC, Huang YC, Wei YH, Chang JS (2009) Biosurfactant-enhanced removal of total petroleum hydrocarbons from contaminated soil. J Hazard Mater 167 609-614.

11. Zheng C, Li Z, Su J, Zhang R, Liu C, Zhao M, et al. (2012) Characterization and emulsifying property of a novel bioemulsifier by Aeribacillus pallidus YM-1. J Appl Microbiol 113: 44-51.

12. Amin GA, Bazaid SA, Abd Elrahim M, Diaeddeen WS (2010) A poten biosurfactant producing bacterial strain for application in enhanced oil recovery applications. J. Pet Environ Biotechnol 1: 104-18.

13. Pirt JS (1975) Principles of microbe and cell cultivation. Blackwell Scientific Publications, Oxford, UK

14. Yang R, Humphrey A (1975) Dynamics, and steady state studies of phenol degradation in pure and mixed cultures. Biotechnol Bioeng 17: 1211-1235

15. Hirose $Y$ (1972) Oxygen transfer. In K. Yamada (ed), The microbial production of amino acids. Wiley p203-226.

16. Cooper DG, MacDonald CR, Duff SJB, Kosaric N (1981) Enhanced production of surfactin from Bacillus subtilis by continuous product removal and metal cation additions. Appl Environ Microbiol 42: 408-412.

17. Khleifat KM (2006) Biodegradation of phenol by Ewingella americana: Effect of carbon starvation and some growth conditions. Process Biochem 41 2010-2016.

18. Leonard D, Lindly ND (1999) Growth of Ralstonia eutropha on inhibitory concentrations of phenol: Diminished growth can be attributed to hydrophobic perturbation of phenol hydroxylase activity. Enzyme Microb Technol 25: 271-277.

19. Ławniczak L, Marecik R, Chrzanowski L (2013) Contributions of biosurfactants to natural or induced bioremediation. Appl Microbiol Biotechnol 97: 2327-2339. 
Citation: Bahobail AS (2016) Degradation of Elevated Concentrations of Phenol Using Two-Stage Immobilized Cell Reactor with Bacillus subtilis and Acinetobacter Iwoffii. J Pet Environ Biotechnol 7: 313. doi: 10.4172/2157-7463.1000313

Page 6 of 6

20. Liu ZF, Zeng GM, Wang J, Zhong H, Ding Y, et al. (2010) Effects of monorhamnolipid and Tween 80 on the degradation of phenol by Candida tropicalis. Process Biochem 45: 805-809.

21. Chrzanowski T, Owsianiak M, Szulc A, Marecik R, Piotrowska-Cyplik A, et al (2011) Interactions between rhamnolipid biosurfactants and toxic chlorinated phenols enhance biodegradation of a model hydrocarbon-rich effluent. Int Biodeter Biodegr 65: 605-611.

22. Ahuja SK, Ferreira GM, Moreira AR (2004) Production of an endoglucanase by the shipworm bacterium Teredinobacter turnirae. J Ind Microbiol Biotechnol 31: $41-47$.

23. Helle SS, Duff SJB, Cooper DG (1993) Effect of surfactants on cellulose hydrolysis. Biotechnol Bioeng 42: 611-617.
24. Whang LM, Liu PWG, Ma CC, Cheng SS (2008) Application of biosurfactants rhamnolipid, and surfactin, for enhanced biodegradation of diesel-contaminated water and soil. J Hazard Mater 151: 155-163.

25. Kwon KH, Yeom SH (2009) Optimal microbial adaptation routes for the rapid degradation of high concentration of phenol. Bioproc. Biosyst. Eng. 32: 435-442.

26. Elias A, Barona A, Gallastegui G, Rojo N, Gurtubay L (2010) Preliminary acclimation strategies for successful start-up conventional biofilters. J Air Waste Manage Assoc 60: 959-967.

27. Rocha LL, Cordeiro RD, Cavalcante RM, Nascimento RFD, Martins SCS, et al. (2007) Isolation and characterization of phenol degrading yeasts from an oil refinery wastewater in Brazil. Mycopathol 164: 183-188. 